\title{
DISCOVERY OF A POPULATION OF THE ENDANGERED RED SISKIN (CARDUELIS CUCULLATA) IN GUYANA
}

\author{
Mark B. Robbins, ${ }^{1,4}$ Michael J. Braun, ${ }^{2}$ and Davis W. Finch ${ }^{3}$ \\ ${ }^{1}$ Division of Birds, Natural History Museum, University of Kansas, Lawrence, Kansas 66045, USA; \\ ${ }^{2}$ Department of Systematic Biology and Laboratory of Analytical Biology, National Museum of Natural History, \\ Smithsonian Institution, 4210 Silver Hill Road, Suitland, Maryland 20746, USA; and \\ ${ }^{3}$ WINGS, 1643 North Alvernon Way, Suite 105, Tucson, Arizona 85712, USA
}

\begin{abstract}
AвSTRACT.-A heretofore unknown population of the endangered Red Siskin (Carduelis cucullata) was discovered in southwestern Guyana, $950 \mathrm{~km}$ from populations along the Venezuela coastal cordilleras. Most Venezuelan populations have been greatly reduced by the pet trade during the past 150 years, thus the newly discovered Guyana population represents an opportunity to insure the survival of this highly endangered species in the wild. Breeding of Guyanese siskins coincides with both breeding periods (May to early July and NovemberDecember) that have been documented in Venezuela. Breeding behavior, vocalizations, feeding habits, and immature plumages are described. Received 12 November 2002, accepted 22 April 2003.
\end{abstract}

Resumen.-Se descubrió una población hasta ahora no conocida de Carduelis cucullata en el suroeste de Guyana, localizada a $\sim 950 \mathrm{~km}$ de poblaciones que se encuentran a lo largo de las cordilleras costeras de Venezuela. Durante los últimos 150 años, la mayoría de las poblaciones venezolanas han sido diezmadas por los traficantes de mascotas, por lo que la población descubierta recientemente en Guyana representa una oportunidad para garantizar la sobrevivencia de esta especie fuertemente amenazada en su ambiente natural. Los períodos reproductivos de C. cucullata en Guyana coinciden con los dos períodos reproductivos reportados en Venezuela (mayo a comienzos de julio y noviembre a diciembre). En este estudio se describen el comportamiento reproductivo, las vocalizaciones, los hábitos de forrajeo y los plumajes de individuos inmaduros.

THE Red Siskin (Carduelis cucullata) has been the object of intense trapping for the international cagebird trade for over 150 years (Coats and Phelps 1985, Collar et al. 1992). Though it once occurred naturally from extreme eastern Colombia across the northern coastal cordilleras of Venezuela (Fig. 1), the latest summaries of its status suggest that most wild populations have been extirpated, with remaining wild populations highly fragmented and consisting of no more than a few hundred individuals per population in extreme eastern Colombia and western and central Venezuela (Coats and Phelps 1985, Collar et al. 1992, López-Lanús 2000, S. Hilty pers. comm.). The species was introduced into Puerto Rico, probably in the 1930s (Raffaele et al. 1998), and there were a handful of records up until 1960 for Trinidad (ffrench 1991), although natural origin of those birds is open to question due to extensive finch trade. In spite of being

${ }^{4}$ E-mail: mrobbins@ku.edu legally protected in Venezuela since 1940 (Coats and Phelps 1985), birds continue to be captured and smuggled out of the country (V. Patterson, American Federation Aviculturists, pers. comm.). Collar et al. (1992) listed the species as category 2 of endangered ("situation serious: action urgent").

On 12 April 2000 in southwestern Guyana, while observing a mixed-species flock at the edge of forest and savanna, M.B.R. heard a small flock of Carduelis-like birds fly overhead. Recognizing that no Carduelis was known from the region, he located the flock a few minutes later, and was stunned to see three adult male and two adult female Red Siskins perched 15 $\mathrm{m}$ above the ground in the top of a leafless tree. During the next hour, he located an additional 7-8 birds (three pairs and at least one female) in an area of $\sim 1.0 \times 0.25 \mathrm{~km}$. Here we document the discovery of that new population of an endangered species and provide natural history data that may help in the conservation of the species in the wild. 


\section{Study AREa And Methods}

Because of the relentless pursuit of this species by the cagebird trade, we have not listed precise localities. To date, the newly discovered siskin population appears to be restricted to the Rupununi savanna of southwestern Guyana (Fig. 1). The Rupununi savanna of Guyana $\left(\sim 13,000 \mathrm{~km}^{2}\right.$; Hills 1976) is a low-lying plain, 100-200 $\mathrm{m}$ in elevation, divided by the western portion of the Kanuku Mountains south of the border town of Lethem $\left(03^{\circ} 23^{\prime} \mathrm{N}, 59^{\circ} 48^{\prime} \mathrm{W}\right)$. The savannas continue for many kilometers to the west in the state of Roraima in Brazil (also known as the Roraima or Rio Branco savanna), and indeed the total area of savanna there is considerably more than in Guyana (Eden 1964, Cole 1986). Interspersed throughout the Rupununi, and adjacent Brazil, are isolated granite mountains that range from small dome-like hills with sparse, semihumid vegetation to relatively tall mountains that cover several square kilometers with more mesic forest (Fig. 2). The rolling plains are covered by grasses, dominated by the perennial bunch grass Trachypogon plumosus (Poaceae) that are interspersed with the dominant savanna tree, Curatella americana (Dilleniaceae; known in Guyana as "caimbé" or "sandpaper tree"). Within the savanna there are pockets, ranging from a several square meters to a few square kilometers, of isolated forest that are known as "bush islands." The entire fringe of the savanna interdigitates with extensive humid forest. Eden (1973) provides details on Rupununi savanna geomorphology and vegetation.

There is a prolonged dry season that typically begins in September and continues into April. The rainy season occurs from late April through August (83\% of the annual rainfall occurs during that period; Eden 1973) often resulting in much of the savanna being flooded from June through early September. Average rainfall at St. Ignatius (just south of Lethem) was 1,621 mm (Eden 1973).

From 10 to 20 April 2000, we surveyed an area of approximately $6 \times 7 \mathrm{~km}$, and between 15 October and 13 November 2000, we inventoried 12 sites covering a total of 122 linear kilometers of appropriate

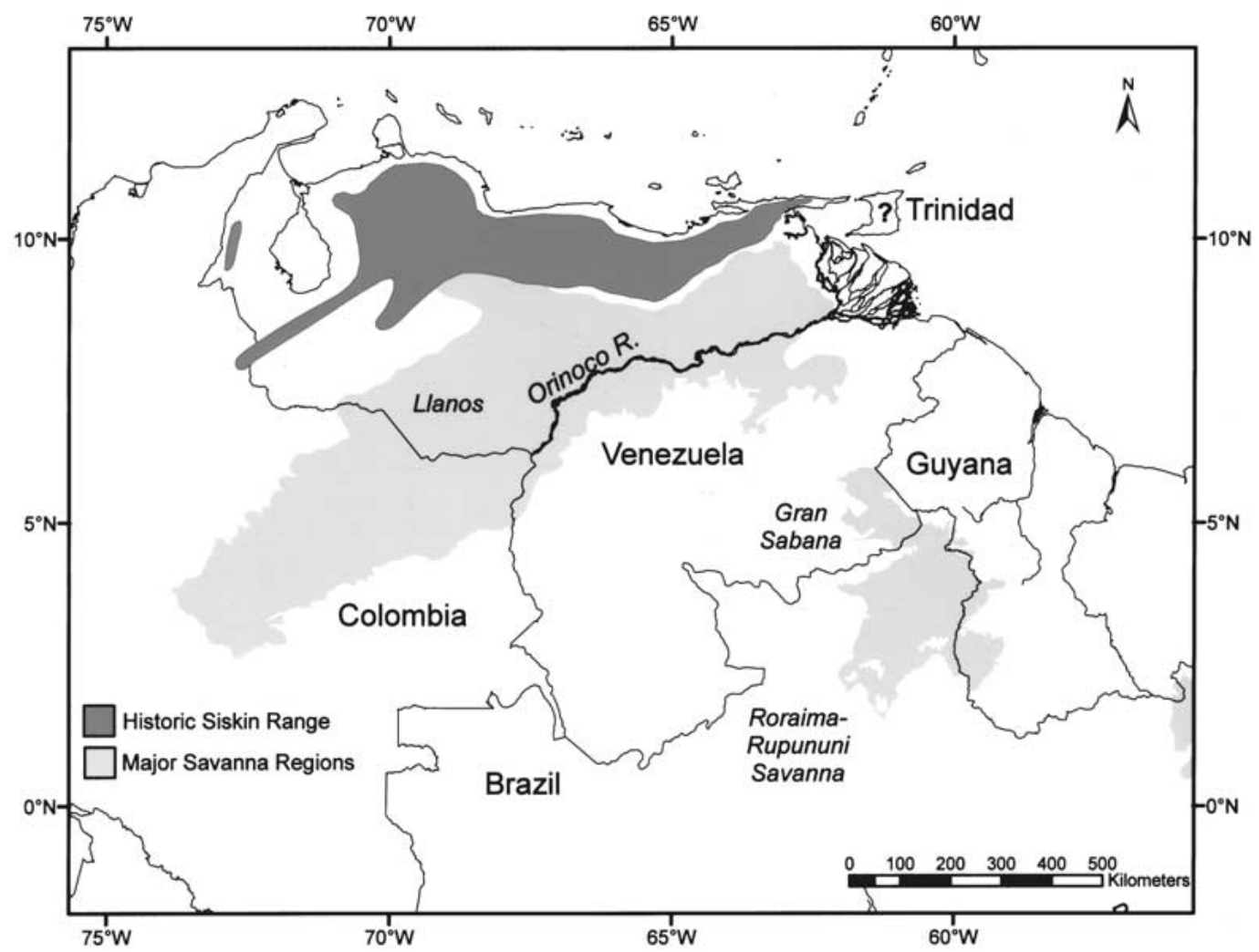

FIG. 1. Dark shading depicts historical range of Red Siskin in Venezuela and lighter shading major savanna regions in northern South America, including the Roraima-Rupununi savanna. The Guyana Rupununi is the site of the newly discovered Guyana population. Savanna distribution from World Wildlife Fund Ecoregions data, available in ARCMAP 8.2. 


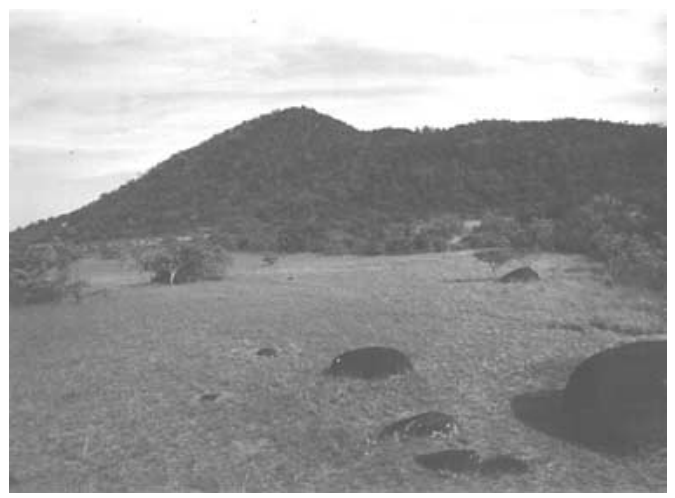

FIG. 2. Red Siskin habitat in the Rupununi, Guyana. Photograph taken from top of granite dome (in foreground). The savanna has been subjected to repeated burning and, as a result, woody vegetation had been reduced and the savanna and deciduous woodland interface was abrupt. Photographed October 2000 by M. Robbins.

habitat-the savanna and semihumid woodland interface-in the Rupununi of Guyana. Because of the area's inaccessibility and rough terrain, surveys were made on foot.

\section{RESULTS}

Status and distribution in Guyana.-With the initial discovery on 12 April 2000 of 12-13 individuals, we made intensive surveys between 12 and 20 April 2000 of an area of approximately 6 $\times 7 \mathrm{~km}$. Censuses revealed a minimum of 85 siskins with perhaps as many as 100 birds present in that relatively small area.

To ascertain extent of the siskin's distribution and status in Guyana, we returned to that region from mid-October through early November 2000. On the basis of our April 2000 observations of siskin habitat preferences, we focused on the savanna and semihumid woodland interface where we covered a total of 122 linear kilometers by foot. A total of 127 siskins were located at 8 of 12 survey sites, or an average of 1.04 siskins $\mathrm{km}^{-1}$. From maps of the Rupununi, we estimate that there are 650 linear kilometers of similar habitat, including all isolated hills and slopes of the Kanuku Mountains. Thus, if our survey was representative, a total of $\sim 675$ siskins would have been encountered if all suitable habitat had been surveyed. However, given that our October-November surveys were conducted mostly during the nonbreeding period when birds were for the most part not vocalizing and were much more nomadic than in April (see below), we suspect the siskin population actually numbers in the low thousands in the Rupununi. Additional surveys of similar intensity were conducted in apparently suitable habitat in adjacent Brazil (May 2001, April 2003) and Guyana (April 2003) by M. Cohn-Haft, L. Naka, M. Torres and M. J. Braun. Those surveys failed to locate additional siskins.

During the October-November surveys, siskins were widely dispersed with only pairs or small groups (maximum of 13 individuals per flock, including immatures) encountered. At one site, a minimum of 60 birds, including at least 5 immatures, were counted in an area $<5$ $\mathrm{km}$ long. At the latter site, both adult and immature males were recorded daily singing persistently (M.B.R. recordings, Macaulay Library of Natural Sounds [MLNS], Cornell University $11840,11848)$. We surmise that the reason the population was densest at that site was because of optimal habitat-a broad area of Curatella americana-dominated scrub interspersed with seasonally flooded marsh that helped reduce frequency and extent of burning at the base of the mountain. As a result, the edge habitats (relatively low-stature second growth) between the semihumid forest and savanna were extensive. In stark contrast, only a few kilometers away, several hills were completely devoid of any woody vegetation because of excessive burning.

Breeding behavior, vocalizations, and general ecology.-Fortunately, our April 2000 trip coincided with breeding at the initial discovery site. On 12 April, siskins clearly were still in the process of forming pairs, as male-male interactions entailed much singing, chasing, and dominantsubordinate displays. Typically, males chased each other in shallow, undulating flights. Those chases did not involve the more exaggerated undulations that pairs were seen making when flying up to $\sim 0.5 \mathrm{~km}$ away from nest sites. Some chases involved a slow butterfly-like flight with deep wing beats. In other cases, a pursuing male approached a perched adversary in a sailing flight, with wings quivering the last 1-2 m before landing. At the end of many chase bouts, often covering only a few meters between trees, males usually landed within 1-2 $\mathrm{m}$ of each other, often at the top of a leafless tree that was taller than the surrounding dominant Curatella 
americana. Upon landing, both males sang, but one male, usually perched slightly below the other, bent forward in a nearly horizontal position with wings slightly extended and drooping and quivering rapidly. That behavior typically would last only a few seconds before one of the birds would fly off or another chase ensued. On occasion, chases escalated to physical contact, with both birds spiraling upward bill to bill, then tumbling downward before resuming the chase.

Several vocalizations were noted. Males were recorded giving a complex song, with a bout lasting up to 2-3 min, with consecutive bouts lasting for as long as $15 \mathrm{~min}$ (MLNS 11840, 11848 ). Both sexes gave simple, single- and double-noted calls that appeared to be associated primarily with mate contact. The single-noted call was typically given while perched, whereas the two-noted call was most often given when birds were in flight (M.B.R. recording, MLNS 11806,11818). Because no birds were marked, and chases were rapid and extensive, we were uncertain of the dominance hierarchy among males and other details of the context of those vocalizations.

The first observation of nest construction was documented on 13 April (nest 1), when D. deFreitas obtained video of a female assembling fibers in the crown of a Curatella tree. Three more nests were found in ensuing days (nests 2, 3, and 4 on 16, 18, and 19 April, respectively). All nests were in Curatella groves at the savanna and semideciduous forest interface at the base of granite slopes. All nests were placed on small branches in dense terminal clusters of Curatella leaves, 4-5 $\mathrm{m}$ up in trees of 5-7 $\mathrm{m}$ height. Nests were deep cups, $10 \mathrm{~cm}$ high and $10 \mathrm{~cm}$ in diameter. Outer portions of the nests were constructed of fibrous bark or grass strips $\sim 0.5 \mathrm{~cm}$ by $2-10 \mathrm{~cm}$. Some nests were lined with fine, white, cotton-like fibers. Nest 2 was still under construction on 20 April, whereas nest 3 appeared complete on 18 April. Other nests were not completed during the observation period, possibly due to interference by other siskins (see below).

M. J. Braun recorded siskin activity in the vicinity of nest 2 for at least $2 \mathrm{~h}$ each day between 0700 and 1100 hours on 16-20 April ( $n=15 \mathrm{~h})$. Nest 4 was discovered $30 \mathrm{~m}$ south-southwest of nest 2 early on 19 April, and was observed alternately with nest 2 on 19-20 April. The most common activities observed were nest visits by building females, when they typically sat in the nest cup or perched on the rim while pulling and tucking nest elements from the outside inward. Fifty-six female visits were recorded with a mean duration of $1.9 \mathrm{~min}$ (range $0.2-11$ min) and mean interval between visits of 4.7 min (range $0.5-25 \mathrm{~min}$ ). Females carried nesting material on $\sim 60 \%$ of visits. Males accompanied females on $95 \%$ of visits, but did not carry nest material or participate in nest construction. When females were at nests, males typically perched silently within $10 \mathrm{~m}$ on exposed branches. Males immediately followed departing females. The only occasions when males left nesting females were to chase other males (see above). Occasionally, when there were no territorial conflicts, males sat silently for an hour or more without singing.

Females building nests 2 and 4 could be distinguished by amount of red on their chests. Female 2 had more red, and dominated female 4 in all interactions. Both females stripped bark for use as nest material from a tangle of dead vines $\sim 10 \mathrm{~m}$ southeast of nest 2 , with female 2 consistently supplanting female 4 at that site. Female 2 also removed large amounts of nest material from nest 4 for use in her nest. Between 0915 and 1015 on 19 April, a female visited nest 4 sixteen times and removed material from the exterior of the nest. On 12 of those visits, the female was seen carrying purloined material directly to nest 2 where it was deposited. Female 4 made two nest building visits to nest 4 during that time. She also twice attempted to supplant female 2 from the vicinity of nest 4 without success. Those attempts were accompanied by much calling, singing, and chasing by both sexes. Purloining of nest material by females from other territories may explain two visits to nest 2, on 17 April, when material from the lower outside of the nest was removed. Similarly, the disintegration and disappearance of nest 1 , located $225 \mathrm{~m}$ south of nest 4, from 13-15 April may have been the result of the same behavior.

Copulations were observed on three occasions, all in the immediate vicinity of nests. Females assumed a horizontal posture similar to the quivering wing display described above when soliciting copulations. For example, at 0730 on 18 April, after a pair foraged for $2-4$ minutes on Curatella seeds they flew a few meters upslope to another Curatella, and a few 
seconds later the female assumed a nearly horizontal position, while extending and quivering her wings. While in this position, she gave a relatively high-pitched "tee-tee-tee-tee-tee-tee-tee" (M.B.R. recording, MLNS 11824). After a few seconds of such solicitation by the female, the male landed briefly next to her before mounting and copulating for $\sim 3 \mathrm{~s}$. The male then flew about a meter higher in the tree and both birds began to wipe their bills on perches. The female continued to give the high-pitched call and quiver her wings for another $20 \mathrm{~s}$. She then flew into an adjacent Curatella that contained nest 3.

Male-male interactions were intense on 12-16 April throughout much of the study site, but a transect through territorites of at least 9 pairs of siskins on 17 April revealed much less interterritorial conflict. That reduced aggression was noted until our departure on 20 April. For example, on 18 April, M.B.R. observed two pairs foraging together from 1-2 $\mathrm{m}$ above ground in a dense stand of the viny Wedelia calycina (Asteraceae). No aggression was observed, even though both pairs foraged within a few centimeters of each other, and at times even probed the same flower bud within a few seconds of each other, for over $15 \mathrm{~min}$ (0830-0845+ hours). Those two pairs were only $65 \mathrm{~m}$ to the west of the pair attending the nest that was discovered a few minutes earlier.

The densely packed territories appeared to be related to a superabundance of food. During our observations, most Curatella had numerous seeds, and fruiting mistletoe (Phoradendron sp.; Loranthaceae) was quite common. In fact, despite extensive searches, we did not find territorial siskins in areas devoid of fruiting mistletoe. Both sexes routinely were observed foraging on those two plants.

During October and November 2000, $\sim 85 \mathrm{~km}$ west of the original discovery site, the first signs of possible breeding during that period were observed. At two different sites, daily singing was recorded and males were observed mateguarding. During that period, siskins appeared to spend more time in semihumid forest, where they were observed feeding on fruit of fig trees (Ficus spp.). By the end of October, Curatella was again flowering and fruiting, and siskins were observed feeding on flower buds and fruit. During both periods, siskins were also observed feeding on grass and herbaceous plant seeds.

Immature plumage and evidence of nesting
success.-In April 2000, all birds ( $n=85$ birds) appeared to be in definitive plumage. In contrast, during late October and early November 2000, at least 16 of 113 individuals identified to plumage state appeared to be immatures. Presumed immature males varied considerably in amount of black plumage on the head, ranging from birds with only a few black feathers (Fig. 3) to some with mostly black heads with a few whitish-gray feathers. Two individuals with mostly black heads had yellow around the base of the hood. One of those males also had a narrow, dull yellow stripe extending ventrally from the near the base of the black hood down to the white of the abdomen and dull yellow in the upper wing coverts. Birds that had entirely dull yellowish heads had a reddish wash on the chest, with a pale orange patch (much less intense than that of an adult female) at the base of the primaries. Other individuals that lacked black in the head completely lacked orange on the chest and on the wings. Coats and Phelps (1985) state that Venezuelan birds undergo an annual prebasic molt beginning in late July and continuing for up to three months. If the Guyana populations follow similar molt schedules, pronounced plumage differences among young males during October and November would presumably represent birds in different stages of transition from juvenal to prebasic plumage.

At the original discovery site, the April 2001 breeding season appeared more advanced than in April 2000, because a newly fledged juve-

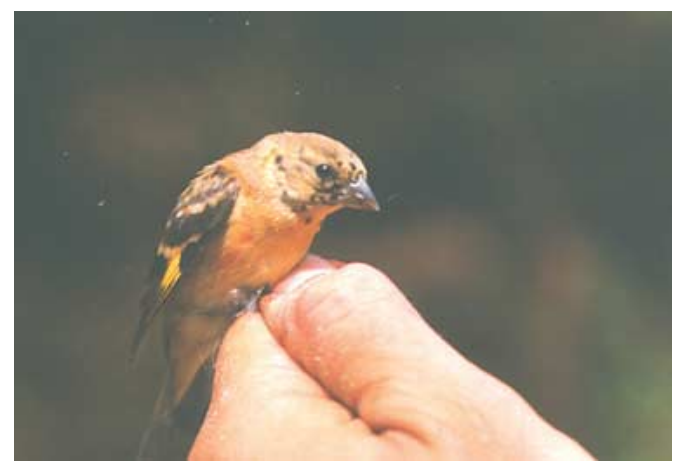

FIG. 3. Immature male Red Siskin that was no more than a few months old. In addition to the obvious black feathers on the head this individual had patches of orangish-red throughout the entire body. Photographed November 2000 by M. Robbins. 
nile was photographed on 11 April 2001 by R. Branson, J. Green, and others. Overall, that bird was pale beige, with some light orange suffusion. The dark cap, hindneck, back, and wing coverts had narrow buffy chestnut streaking and two conspicuous wingbars were edged with cream. The throat and upper chest had light orange streaking, and the breast, abdomen, and undertail coverts were creamy beige. Tail feathers were only partially grown. Irides were dark, bill black, and tarsi and feet pinkish with light bluish nails.

\section{DisCUSSION}

Origin and isolation.-The newly discovered population of Red Siskins appears to be isolated by $\sim 950 \mathrm{~km}$, with intervening rain forest and tepui mountains, from all known Venezuelan populations, extirpated or extant. If we assume a vicariant origin, geographic barriers and the geological and vegetational history of northern South America would seem to indicate that this new population may have been been isolated from the known Venezuelan populations for at least 8000-10,000 years (Van der Hammen 1983).

A number of savanna, dry forest, and forestedge-inhabiting avian species that are found in northern Venezuela and Guyana, but not the Venezuelan Gran Sabana, have disjunct populations in the Roraima-Rupununi savanna (G. F. Mees unpubl. manuscript). Haffer (1974) postulated that presence of the nominate form of the Rufous-tailed Jacamar (Galbula ruficauda) in that region was the result of past savanna connections with coastal Venezuela and Guyana. Indeed, pollen core profiles from Guyana demonstrate considerable fluctuation in dominant vegetation cover, that ranged from rain forest to savanna, during the late Pleistocene and Holocene (Van der Hammen 1983). We presume the Rupununi Red Siskin population is another example of a species that once had a continuous distribution via the savanna and dry woodland connection between the Roraima-Rupununi and coastal Guyana and Venezuela savannas.

Because the Red Siskin is a seminomadic, flocking species that breeds colonially, the possibility that it reached Guyana by recent, long-distance dispersal must be considered. The Rupununi siskins do not appear to have diverged much in plumage from Venezuelan populations. In comparison of Rupununi adults with adult Venezuela specimens, we did not note any plumage or morphometric differences. Genetic comparisons are planned that will help determine both extent of divergence and inherent genetic diversity of the Guyanese population. Those data might be useful in distinguishing various origin hypotheses.

The popularity of the Red Siskin as a cagebird raises the possibility that the Guyana population may have been introduced. We believe that is highly unlikely because the species seems to be unknown in the local cagebird trade, and the area where it is found in Guyana is remote and sparsely inhabited by humans. As mentioned above, a disjunct Rupununi and northern Venezuela distribution is seen in many other species and subspecies that clearly did not result from introductions. Nonetheless, an introduction scenario would be hard to distinguish from recent long-distance dispersal on the basis of plumage characteristics. Regardless of origin, presence of a healthy population of this critically endangered bird in Guyana has positive implications for survival of the species.

Although the Rupununi population is clearly disjunct from all previously known Red Siskin populations, it is possible that some other populations remain undetected in the intervening area. Unlike the Rupununi, most areas of suitable habitat in central and southeastern Venezuela have been relatively well studied, and seem unlikely to harbor siskin populations. The north Rupununi region had also received a moderate amount of attention without detection of this species. Thus, the most promising areas are regions of savanna and dry forest habitat in southwestern Guyana and the Roraima state of Brazil. Surprisingly, additional surveys in those regions failed to locate more siskins. Although it seems likely that siskins use those areas at least occasionally, for example, in years when Curatella fruit is abundant, the core range of the Guyana population appears to be restricted to the Rupununi.

Breeding.-Our observations of breeding coincide with both breeding periods (May to early July and November-December), that have been documented in Venezuela (Coats and Phelps 1985). Level of breeding activity documented in April 2000 coupled with presence of a relatively high percentage of immatures during October and November suggest that 
the principal breeding period is at the onset of the rainy season in Guyana, as is the case in Venezuela. At least during the nonbreeding period, Venezuelan and Guyanese siskins use the savanna-forest ecotones, and at least one of the foods (Wedelia [Asteraceae]) at both localities is shared. However, birds in central Venezuela and along the base of the eastern slope of the Venezuelan Andes breed at higher elevations, $600-1,300 \mathrm{~m}$, and in more mesic situations than the Guyanese birds (Coats and Phelps 1985, S. Hilty pers. comm.).

Conservation.-Because of the pet trade, the situation of the Red Siskin in Venezuela is quite bleak. Fortunately, the newly discovered Guyana population presents a unique opportunity to ensure that this species does not become extinct in the wild. Much of the known Guyana range is on a leased cattle ranch managed by persons concerned about conservation in general, and siskins in particular. Aside from reduction in frequency of burning, which is used to generate better forage for cattle, that area needs little habitat management for siskins. Thus, as in Venezuela, the principal concern is cagebird trappers. Guyanese bird trappers are ubiquitous throughout the Rupununi region. Some are familiar with the siskin, but to date they claim there is no local market for the species. Trappers apparently release netted siskins and focus on capturing two finches that are in high demand because of their singing ability: the Largebilled Seed-Finch (Oryzoborus crassirostris) and the Chestnut-bellied Seed-Finch (Oryzoborus angolensis). Both seed-finches have suffered significant declines in Guyana because of trapping, and if a black market develops for the Red Siskin it quickly could suffer the same fate.

An effective management plan for the Guyanese population may include (1) legal protection (see below); (2) education for prevention of trapping and reducing fire frequency; (3) establishment of one or more protected areas to preserve optimal habitat; (4) ecological studies to determine crucial factors for population maintenance; (5) above mentioned genetic studies for devising an effective management plan for the Guyanese population.

The Red Siskin is provided international legal protection by the Convention of International Trade in Endangered Species of Wild Fauna and Flora (CITES) (Appendix 1) and by the U.S. Endangered Species Act. Prohibition of trade of Red Siskins within Guyana has been recommended by the Management Authority of the Guyanese Wildlife Division, and a proposal for endangered species listing is pending in the Guyana government. Despite national and international protection, Red Siskins apparently are still being smuggled out of Venezuela (Y. Patterson, American Federation of Aviculture, pers. comm.). Indeed, Coats and Phelps (1985) provided details on how birds smuggled out of Venezuela reach the European market via countries such as Holland which still are not signatories of CITES. If the Red Siskin is truly absent from Brazil, then protection of the Guyanese population becomes critically important. Survival of this species in the wild will require international cooperation among law enforcement agencies, landowners, conservationists, and aviculturists.

Within the Guyana range of the siskin, we hope that the combination of the relative inaccessibility of the area and opportunity for ecotourism through the ranch will ensure that this entire area will be protected for not only siskins but for a number of other declining and local avian species, such as the Bearded Tachuri (Polystictus pectoralis). Other high-profile species in need of conservation, such as the giant anteater (Myrmecophaga tridactyla), jaguar (Panthera onca), and Jabiru (Jabiru mycteria), all of which are still fairly common in that region, would also benefit from siskin protection.

\section{ACKNOWLEDGMENTS}

D. Clarke identified plants and helped with the vegetation profile of the discovery site. T. Hollowell produced the map. R. Branson and J. Green provided photos and description of a juvenile siskin. S. Hilty kindly shared unpublished information on siskin status in Venezuela. J. C. Anderton painted the cover illustration, and R. Branson and J. Green provided photos and description of a juvenile siskin. G. Budney provided catalog numbers for material deposited at the Macaulay Library of Natural Sounds, Cornell University. The American Bird Conservancy, American Federation of Aviculturists, Bushnell Sports Optics, Conservation International, and National Aviary supported the October and November 2000 field work. National Aviary also supported the Brazil surveys. The National Biodiversity Committee of the Environmental Protection Agency, the Ministry of Amerindian Affairs, and the University of Guyana provided permission and help for our work. We thank our field colleagues B. Schmidt, C. Milensky, and B. 
Barber. D., S., and J. deFreitas; A. Narain; A. Holland; and C. Perry helped immensely with logistics. T. Peterson, D. Stotz, M. Cohn-Haft, and P. Escalante made constructive comments on the manuscript. This is number 73 in the Smithsonian's Biological Diversity of the Guianas Program publication series.

\section{Literature Cited}

Conts, S., And W. H. Phelps, Jr. 1985. The Venezuelan Red Siskin: Case history of an endangered species. Ornithological Monographs, no. 36.

Cole, M. M. 1986. The Savannas. Biogeography and Geobotany. Academic Press, London.

Collar, N. J., L. P. Gonzaga, N. Krabbe, A. Madroño Nieto, L. G. Naranjo, T. A. Parker III AND D.C. WEGE. 1992. Threatened birds of the Americas. The ICBP/IUCN Red Data Book, 3rd ed., part 2. International Council for Bird Protection, Cambridge, United Kingdom.

EDEN, M. J. 1964. The savanna ecosystemNorthern Rupununi, British Guiana. McGill University Savanna Research Project, Savanna Research Series, no. 1, Montreal, Québec.

EDEN, M. J. 1973. The savanna environment Guyana. McGill University Savanna Research
Project, Savanna Research Series, no. 17, Montreal, Québec.

FFRENCH, R. 1991. A Guide to the Birds of Trinidad and Tobago, 2nd ed. Cornell University Press, Ithaca, New York.

HAFFER, J. 1974. Avian speciation in tropical South America. Publications of the Nuttall Ornithological Club, no. 14.

Hills, T. L. 1976. The savanna biome: A case study of human impact on biotic communities. McGill University Savanna Research Project, Savanna Research Series, no. 19, Montreal, Québec.

López-LANús, B. 2000. Carduelis cucullatus aun sobrevive en Colombia. Boletín Soc. Antioqueña Ornitologia 11:89-90.

Raffaele, H., J. Wiley, O. Garrido, A. Keith, and J. Raffaele. 1998. A Guide to the Birds of the West Indies. Princeton University Press, Princeton, New Jersey.

VAn Der Hammen, T. 1983. The palaeoecology and palaeogeography of savannas. Pages 19-35 in Ecosystems of the World 13: Tropical savannas (F. Bourlière, Ed.). Elsevier, Amsterdam.

Associate Editor: P. Escalante 